\title{
Transgenic potato tubers with overexpression of 14-3-3 protein in growing rat diets. 1. Selected hormone activities and liver function status*
}

\author{
I. Kosieradzka ${ }^{1}$, E. Sawosz ${ }^{1}$, J. Skomial ${ }^{1}$ and J. Szopa ${ }^{2}$ \\ Warsaw Agricultural University, \\ ${ }^{1}$ Department of Animal Nutrition and Feed Science \\ Ciszewskiego 8, 02-786 Warsaw, Poland \\ ${ }^{2}$ Agricultural University of Wroctaw, Institute of Biochemistry and Molecular Biology \\ Przybyszewskiego 63, 51-148 Wroctaw, Poland
}

\begin{abstract}
In a 4-week experiment, growing rats were fed diets containing 30\% transgenic potatoes with overexpression of P14-3-3 protein, non-transgenic dehydrated potato tubers of the same variety (Desiree), or a control diet. The activity of dehydroepiandrosterone (DHEA) as well as increases in the concentrations of $\mathrm{NO}_{3}^{-}$ions, $\mathrm{Fe}$ and $\mathrm{Zn}$ in the liver of rats fed diets containing transgenic potatoes were observed. The reaction might be related to oxidative stress linked to the altered chemical composition of potato tubers resulting from transgenesis, changed concentrations of some minerals or biologically active substances.
\end{abstract}

KEY WORDS: transgenic potato, rats, selected hormone activities, liver

\section{INTRODUCTION}

Assessment using transgenic plants in human and animal diets requires many nutritional experiments, including evaluation of potential cytotoxic risk and mutagenic or immunosupressive interactions. Modification of 14-3-3 protein, which is a regulator of numerous processes in plant cells modulating protein metabolism and the activity of key enzymes connected with $\mathrm{N}$ and $\mathrm{C}$ metabolism in plants, influences not only the content of nutrients in potato tubers of transgenic plants but can also change the content of biologically active substances (Wilczyński et al., 1998). Earlier experiments did not find any significant effects

\footnotetext{
* Supported by the State Committee for Scientific Research, Grant No. 3P06Z00925

${ }^{1}$ Corresponding author: e-mail: kosieradzka@delta.sggw.waw.pl
} 
of adding potatoes with modified 14-3-3 protein to the diet on the growth of rats (Kosieradzka et al., 2004). The aim of the present study was the examination of the influence of genetically modified potatoes with overexpression of 14-3-3 protein on the level of selected hormones and indicators of liver functional status.

\section{MATERIAL AND METHODS}

The experimental material consisted of potato tubers of Solanum tuberosum L. cv. Desiree with increased synthesis of protein 14-3-3 (derived from Cucurbita pepo cDNA) developed at the Department of Genetic Biochemistry of University of Wrockaw. The transgenic potato variety contained more crude protein in DM of tubers than conventional varieties (16.2 vs $10.7 \%$ ), fat ( 0.6 vs $0.2 \%)$, Fe (130 vs 58 $\mathrm{ppm})$ and less $\mathrm{Zn}(29 \mathrm{vs} 34 \mathrm{ppm})$. Male rats from the outbred $\mathrm{IF}_{\mathrm{z}} \mathrm{Jaz}$ herd with a mean body weight of $150 \mathrm{~g}$ were allotted to 3 groups, and were kept in individual cages. During the four-week experiment the rats received an isoproteinous diet containing $30 \% \mathrm{DM}$ of steamed and dried $\left(50^{\circ} \mathrm{C}\right)$ tubers of transgenic and non-transgenic cv. Desiree potatoes. The control group was fed the standard casein diet. All diets were supplemented with $3.5 \%$ mineral mixtures (AIN-93, ICN). At the end of the experiment the rats were fasted for $12 \mathrm{~h}$ and euthanized by ketamine overdose, blood was sampled from hearts, and livers were removed and frozen $\left(-70^{\circ} \mathrm{C}\right)$. In liver tissue, $\mathrm{Fe}$ and $\mathrm{Zn}$ were determined by FAAS, $\mathrm{NO}_{3}^{-}$and $\mathrm{NO}_{2}^{-}$by HPLC (Waters). In blood serum, glucose, creatinine, cholesterol, HDL, triglycerides, urea $\mathrm{N}$, total protein, asparagine transferase (AST) and alanine transferase (ALT) were determined using Vitros DT II kits (Johnson and Johnson, USA). Serum steroid hormone dehydroepiandrosterone (DHEA) was measured by RIA kits (DSL-9000 Active DHEA, Diagnostic Systems Laboratories, Inc., Webster, TX). Concentrations of plasma triiodothyronine, $\left(\mathrm{T}_{3}\right)$, thyroxine $\left(\mathrm{T}_{4}\right)$ were assayed by a chemico-luminescent method using DPC-Immulete kits (Immulete 2000 automated enzyme immunoassay analysers). The results were subjected to statistical analysis by single-factor analysis of variance ANOVA and Duncan's range test, using Statgraphic 4.1 Plus software package.

\section{RESULTS AND DISCUSSION}

Oxidative stress caused by diet composition may result in increased thyroid hormone activity and lead to intensification of catabolism, thermogenesis and increase in tissue oxygen requirements. Giving diets containing 30\% transgenic or non-transgenic potatoes caused a statistically significant increase in thyroxine $\left(\mathrm{T}_{4}\right)$ levels. This thyroid hormone can induce liver oxidative stress leading to enhancement in lipid and protein oxidation and to nitration through peroxynitrite formation (Radi et al., 1995). The increase of $T_{4}$ activity was not accompanied by changes in the values 
of biochemical parameters connected with lipid and protein metabolism. However, in the livers of rats fed diets with potatoes, a statistically significant increase in $\mathrm{NO}_{3}^{-}$ ions in comparison with the control group was found. Feeding transgenic potatoes in comparison with the non-transgenic ones increased $\mathrm{NO}_{3}^{-}$ion levels in the liver (Table 1). The biological significance of the oxidative modification of proteins in liver induced by thyroid-hormone oxidative stress could be connected with loss of protein function and increased protein degradation (Tapia et al., 1999).

Table 1. Relative liver weight, concentration of nitrite and nitrate ions and Fe, $\mathrm{Zn}$ in liver tissue (fresh matter) biochemical parameters, thyroid hormones $\left(\mathrm{T}_{3}, \mathrm{~T}_{4}\right)$ and dehydroepiandrosteron (DHEA) in blood serum

\begin{tabular}{|c|c|c|c|c|c|}
\hline & \multirow{2}{*}{ Control } & \multicolumn{2}{|c|}{ Potato } & \multirow{2}{*}{ SEM } & \multirow{2}{*}{$\mathrm{p}$} \\
\hline & & non-transgenic & transgenic & & \\
\hline \multicolumn{6}{|l|}{ Liver } \\
\hline liver weight $\mathrm{mg} / 100 \mathrm{~g} \mathrm{BW}$ & 4.97 & 4.96 & 4.94 & 0.1528 & 0.0064 \\
\hline $\mathrm{NO}_{2} \mathrm{mg} / \mathrm{kg}$ & $<0.07$ & $<0.07$ & $<0.07$ & - & - \\
\hline $\mathrm{NO}_{3} \mathrm{mg} / \mathrm{kg}$ & $1.79^{\mathrm{A}}$ & $2.40^{\mathrm{B}}$ & $3.44^{\mathrm{C}}$ & 0.0272 & 0.0001 \\
\hline $\mathrm{Fe} \mathrm{mg} / \mathrm{kg}$ & $36.0^{\mathrm{A}}$ & $68.7^{\mathrm{B}}$ & $84.2^{\mathrm{C}}$ & 0.1164 & 0.0000 \\
\hline $\mathrm{Zn} \mathrm{mg/kg}$ & $27.4^{\mathrm{A}}$ & $27.0^{\mathrm{A}}$ & $28.0^{\mathrm{B}}$ & 0.0759 & 0.0000 \\
\hline \multicolumn{6}{|l|}{ Serum } \\
\hline aspargine transferase $\mathrm{U} / \mathrm{L}$ & 192.8 & 138.0 & 147.0 & 34.7939 & 0.5076 \\
\hline alanine transferase $\mathrm{U} / \mathrm{L}$ & 44.5 & 44.5 & 43.4 & 4.2988 & 0.2975 \\
\hline cholesterol, $\mathrm{mmol} / \mathrm{L}$ & 1.82 & 1.79 & 1.69 & 0.0712 & 0.4540 \\
\hline $\mathrm{HDL}, \mathrm{mmol} / \mathrm{L}$ & 1.07 & 0.96 & 0.97 & 0.0438 & 0.2171 \\
\hline triglycerides, $\mathrm{mmol} / \mathrm{L}$ & 1.72 & 1.82 & 1.25 & 0.2294 & 0.2100 \\
\hline urea $\mathrm{N} \mathrm{mmol} / \mathrm{L}$ & 3.36 & 3.58 & 3.92 & 0.1802 & 0.1280 \\
\hline creatinine, $\mu \mathrm{mol} / \mathrm{L}$ & 30.94 & 33.15 & 31.82 & 1.9601 & 0.7307 \\
\hline $\mathrm{T}_{3}, \mu \mathrm{g} / \mathrm{dL}$ & 149.5 & 159.25 & 149.25 & 6.7464 & 0.5152 \\
\hline $\mathrm{T}_{4}, \mu \mathrm{g} / \mathrm{mL}$ & $58.18^{\mathrm{A}}$ & $73.95^{\text {в }}$ & $75.75^{\text {в }}$ & 4.4691 & 0.0404 \\
\hline DHEA, $\mu \mathrm{g} / \mathrm{mL}$ & $1.40^{\mathrm{A}}$ & $1.30^{\mathrm{A}}$ & $1.68^{\mathrm{C}}$ & 0.0276 & 0.0000 \\
\hline
\end{tabular}

There were no statistically significant differences in asparagine and alanine transferase activities in the blood serum of rats fed the experimental and control diets. Increased intensity of lipid degradation in liver cells was accompanied by increased concentrations of Fe and $\mathrm{Zn}$ (Table 1). The increased accumulation of essential metals (Fe, $\mathrm{Zn}$ ) and nitrate ions in liver tissue may be associated with liver tissue damage (Chen et al., 1998). Iron may act as a catalyst for the Fenton reaction and play a role in initiating the lipid peroxidation of this organ. In the blood of rats fed diets with transgenic potatoes, the concentration of DHEA was higher than in other groups, which could be a symptom of earlier onset of puberty of the males in this group (Table 1). Precise evaluation of the reasons for degradation of liver tissue and hormone activity requires further study of 
the concentration of biologically active substances in tubers of both transgenic and non-transgenic potato forms (glycoalcaloids, polyphenolics, etc.) and also carrying out long-term experiments on the use of pure substances isolated from the tubers in synthetic diets.

\section{CONCLUSIONS}

Giving growing rats diets containing 30\% dehydrated potatoes with overexpression of protein 14-3-3 caused a change in the activity of DHEA, increased the concentration of $\mathrm{NO}_{3}{ }^{-}$ions and $\mathrm{Fe}$ and $\mathrm{Zn}$ in liver in comparison with the tissues of rats fed diets with non-transgenic potatoes. The reaction might be related to changed concentrations of some minerals in the diets and oxidative stress linked to the altered chemical composition of potato tubers resulting from transgenesis.

\section{REFERENCES}

Chen Ch.-Yu., Huang Y.-L, Lin. T.-H., 1998. Effects of vitamin A pretreatment on nickel-induced lipid peroxidation and concentration of essential metals in liver, kidney and lung of mice. Arch. Toxicol. 72, 381-386

Kosieradzka I., Sawosz E., Pastuszewska B., Żuk M., Szopa J., Bielecki W., 2004. Effect of feeding potato tubers modified by 14-3-3 protein overexpression on metabolism and health status of rats. J. Anim. Feed Sci. 13, 329-339

Radi R., Rubbo H., Freeman B., 1995. The double-edged action of nitric oxide on free radicalmediated oxidations. J. Braz. Assn. Adv. Sci. 47, 288-296

Sugihara N., Arakawa T., Ohnishi M., Furuno K., 1999. Anti-and pro-oxidative effects of flavonoids on metal-induced lipid hydroperoxide- dependent lipid peroxidation in cultured hepatocytes loaded with alpha-linolenic acid. Free Radical Biol. Med. 27, 1313-1323

Tapia G., Cornejo P., Ferna'ndez V., Videla L., 1999. Protein oxidation in thyroid hormone-induced liver oxidative stress: relation to lipid peroxidation. Toxicol. Lett. 106, 209-214

Wilczyński G., Kulma A., Feiga I., Wenczel A., Szopa J., 1998. Manipulating of 14-3-3 protein expression results in the changes of catecholamine content in potato plants. Cell. Mol. Biol. Lett. 3, 75-91

\section{STRESZCZENIE}

Transgeniczne ziemniaki $\mathrm{z}$ nadekspresją biała 14-3-3 w diecie dla rosnących szczurów. 1. Aktywność wybranych hormonów i stan funkcjonalny wątroby

W 4-tygodniowym doświadczeniu rosnącym szczurom podawano izobiałkowe diety $\mathrm{z}$ $30 \%$ udziałem suszonych bulw ziemniaków transgenicznych z nadekspresją białka 14-3-3 lub nietransgenicznych odmiany Desiree oraz standardową dietę kontrolną. Stwierdzono zmianę aktywności dehydroepiandrosteronu (DHEA), zwiększenie koncentracji jonów $\mathrm{NO}_{3}^{-}$, oraz Fe i $\mathrm{Zn} \mathrm{w}$ tkance wątroby szczurów otrzymujących diety z ziemniakami transgenicznymi. Reakcja organizmu może mieć związek ze stresem oksydacyjnym wywołanym zmienionym, w wyniku transgenezy, składem ziemniaków, zróżnicowaną zawartością niektórych składników mineralnych lub substancji biologicznie czynnych. 